\title{
Type-2 Diabetes, a Global Epidemic
}

\author{
Gundu HR Rao* \\ Emeritus Professor, University of Minnesota, USA
}

Submission: February 03, 2017; Published: February 08, 2017

*Corresponding author: Gundu HR Rao, Emeritus Professor, Laboratory Medicine and Pathology, Lillehei Heart Institute, Founder CEO, South Asian Society on Atherosclerosis and Thrombosis (SASAT), University of Minnesota, USA, Email: gundurao9@gmail.com

\section{Commentary}

Type 2 diabetes is a global public health crisis and contributes significantly to the healthcare burden. Excess weight and obesity to a large extent, are the driving force for the global epidemics of type-2 diabetes. NCD Risk Factor Collaboration, in their seminal article in the Lancet (April 2016) concluded that, "if the post-2000 trends continue in the incidence and rise of diabetes, the probability of meeting the global target of halting the rise in the prevalence of diabetes by 2025 , to the 2020 level worldwide is lower than one percent. According to the Institute for Health Matrics and Evaluation (IHME), today 2.1 billion people- nearly $30 \%$ of the global population, are either obese or overweight-a new, first-of-a-kind analysis of trend data from 180 countries. Since 1980 , obesity has increased worldwide by two fold and diabetes four fold. Patients with diabetes have a two threefold higher risk for developing cardiovascular disease and cerebrovascular disease.

According to the Diabetes Atlas of the world, India has over 70 million diabetic subjects and China over 110 million diabetics [1]. The risk of acute vascular events in diabetic population is 2-3 times higher than in non-diabetic population. Compared with Western population, Asians develop diabetes at a younger age. Asians account for $60 \%$ of the global diabetic population. Unlike in the western countries, obesity per se does not directly correlate with incidence or rate of diabetes. In India, for instance, in spite of a relatively low prevalence of obesity (based on BMI), there exist a high rate of diabetes. Studies at the University of Minnesota in collaboration with the staff of Madras Diabetes Research Foundation (MDRF), Chennai, India, demonstrated that compared to the American adults based on waist/hip ration, Asian population exhibits "normal-weight metabolically obese' phenotype [2,3]. In view of this unique distribution of fat (Visceral Fat) there appears to be a greater accumulation of abdominal fat but with lean muscle mass, predisposing this population to increased prevalence of insulin resistance. In addition, low grade systemic inflammation, seems to be one of the underlying cause of the pathogenesis of type- 2 diabetes.
We the members of the South Asian Society on Atherosclerosis and Thrombosis (SASAT) have been advocating early detection of the risks for diabetes and a robust management strategy of identified risks, for preventing diabetes-related clinical complications. Several clinical trials have demonstrated that diabetes and its clinical complications are preventable. In China, after a 6-year intervention with diet, exercise and lifestyle modifications, 31\% (diet alone) 36\% (exercise) and 42\% (diet and exercise) reduction in risk has been reported [4]. In a 14year follow-up with combined life style intervention, they demonstrated 51\% lower risk. Both Finnish and the US Diabetes Prevention Program using lifestyle intervention demonstrated significant reduction (58\%) in diabetes incidence [5-7].

As part of the 2020 impact goals, the American Heart Association (AHA) has set out seven ideal health goals; not smoking, maintaining normal weight, increased physical activity, a healthy diet, normal blood lipid levels, normal blood pressure and a normal fasting glucose. An analysis of the National Health and Nutritional Examination Survey (NHANES) showed, that individuals who met five of the seven ideal metrics of AHA, had a 78\% reduction in the hazard ratio for all cause-mortality [8]. From the INTERHEART study, which included 52 countries, it is estimated that modifiable risk factors account for $90 \%$ of the population attributable risk for heart disease in Men and $94 \%$ of the risk in Women [9]. As is the case with majority of clinical trials, the INTERHEART studies looked at the modifiable risk factors in developing the prevention strategies. However, a recent article by Khera et al. [10] in N. Engl J. Med. showed that in four studies with over 55,000 participants, a favorable lifestyle intervention was associated with nearly $50 \%$ lower relative risk for Coronary Artery Disease, in spite of the genetic risk [10]. In a recent UK study, with over half million subjects providing the baseline data, researchers showed that incorporation of increased levels of physical activity as part of the commute to work, could reduce obesity among middle-aged adults in the UK [11]. 
I would like to conclude this short commentary with a statement from Professor David Katz, director of Yale University Prevention Research Center and president of the American College of Life Style Medicine, "There is no pill, and there never will be any pill, that can reduce burden of chronic disease in the way that a healthy lifestyle can". (Lifestyle Interventions. Medscape Apr 22, 2105).

\section{References}

1. International Diabetes Federation IDF. Diabetes Atlas. Epidemiology and Morbidity. In: International Diabetes Federation.

2. Bajaj HS, Perreira M, Anjana M, Deepa R, Mohan V et al. (2014) Comparison of relative waist circumference between Asian Indian and US Adults. J Obesity 2014: 461956.

3. Mohan V, Rao GHR (2007) Type-2 diabetes in South Asians: Epidemiology, Risk Factors and Prevention. JP Medical Publishers, New Delhi, India.

4. Pan XX, Li GW, Hu YH, Wang JX, Yang WY, et al. (1997) Effects of diet and exercise in preventing NDDM in people with impaired glucose tolerance. The Da Quing IGT and Diabetes Studies. Daib Care 20(4): 537-544.

5. Lindstrom J Ilane-Parikka P Peltonen M, Aunola S, Eriksson JG, et al. (2006) Sustained reduction in the incidence of type-2 diabetes by life style interventions: Follow up of the Finnish Diabetes Prevention Studies. Lancet 368(9548): 1673-1679.

6. Knowler WC, Barret-Connor E Fowler SE et al. (2002) Diabetes Prevention Program Research Group. Reduction in the incidence of type-2 diabetes with life style intervention or metformin. $\mathrm{N}$ Engl J Med 346: 393-403.

7. Ramachandran A, Snehalatha C, Mary S, Mukesh B, Bhaskar AD, et al. (2006) Indian Diabetes Prevention Program (IIDP). Diabetologia 49(2): 289-297.

8. Lloyd-Jones, Hong Y, Labarthe D, Mozaffarian D, Appel LJ, et al. (2010) Amer Heart Assoc Strategic Planning Task Force and Statistics Committee. Defining and setting National Goals for cardiovascular health promotion and disease reduction. The Amer Heart Assoc Strategic and Impact Goal Through 202 and beyond. Circ 121(4): 586613.

9. Yusuf S, Harker S, Ounpuus, Dans T, Avezum A, et al. (2004) INTERHEART Study Investigation: Effect of potentially modifiable risk factors associated with myocardial infarction in 52 countries (the INTEHEART Study) Case Control Study. Lancet 364(9438): 937-952.

10. Khera AV, Emdin CA, Drake I et al. (2016) Genetic risk, adherence to healthy life style single and relative risk of coronary artery disease. N Engl J Med 375: 2349-2358.

11. Flint E, Webb E, Cummins S (2016) Change in commute mode and body-mass index: Prospective, longitudinal evidence from UK Bio bank. Lancet Public Health 1(2): e46-55.

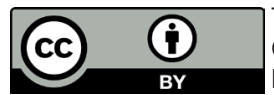

his work is licensed under Creative Commons Attribution 4.0 Licens DOI: 10.19080/JETR.2017.01.555552

\begin{tabular}{l} 
Your next submission with Juniper Publishers \\
will reach you the below assets \\
- Quality Editorial service \\
- Swift Peer Review \\
- Reprints availability \\
- E-prints Service \\
- Manuscript Podcast for convenient understanding \\
- Global attainment for your research \\
- Manuscript accessibility in different formats \\
( Pdf, E-pub, Full Text, Audio) \\
- Unceasing customer service \\
Track the below URL for one-step submission \\
https://juniperpublishers.com/online-submission.php \\
\hline
\end{tabular}

